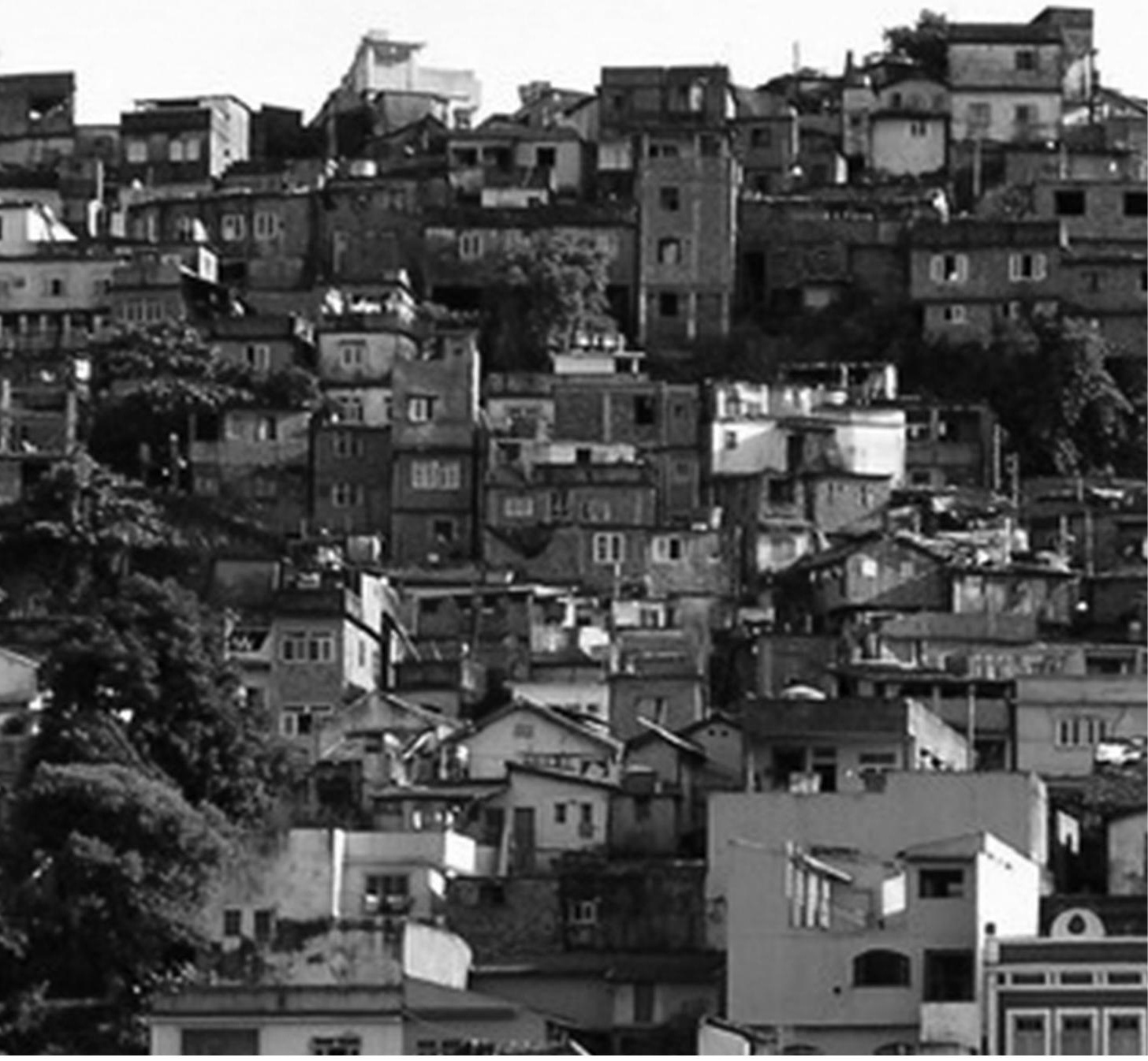

AIBR

Revista de Antropología Iberoamericana

www.aibr.org

Volume 12

Number 1

January - April 2017

Pp. $77-102$

Madrid: Antropólogos Iberoamericanos en Red. ISSN: 1695-9752

E-ISSN: 1578-9705

\section{Garden of Stories: Rereading the violence towards women in a Río Slum}

Marisa Antunes Santiago

F. Manuel Montalbán Peregrín

Universidad de Málaga

Hebe Signorini Gonçalves

Universidade Federal do Rio de Janeiro (UFRJ)

Received: January 28, 2016

Accepted: February 10, 2017

DOI: 10.11156/aibr.120105e
Translation:

Ashley Woodward

(The State University of New York at Potsdam) 


\section{RESUMEN}

This article is the result of research on violence against women in Brazil. It arises from the work of a psychologist in an integral institution of the national prevention policy to prevent and cope with such violence, located in a favela in Rio de Janeiro. The contact with users of this institution allowed for access to the biographies of women whose lives were always crossed by various forms of violence. The desire to understand this universe and to make/ create effective interventions possible stimulated the development of this research. In spite of the fact that in Brazil a specific legislation exists to cope with the problem, the statistics continue to be alarming and the naturalization of violence in the favelas is constant. Our aim is to understand the peculiar trajectories of, and define the condition of, being a woman who suffers violence in a favela. In sum, we seek to understand how violence against women is (re)signified in the context of urban violence. For this we use qualitative methodologies: participant observation, life stories, and discourse analysis from a biographical-narrative approach. Our conclusions show the need to recognize women are in a particular situation of vulnerability. A set of inequalities are associated with violence and we need a comprehensive understanding of the scenario in which these women live in order to face the problem. The challenge is to develop comprehensive policies and to act on alternative forms of confrontation that are not another form of violence, guaranteeing the full experience of citizenship.

PALABRAS CLAVE

Violence against the woman, urban violence, favela, life stories, discourse analysis. 


\section{Introduction}

The development of this study is the fruit of a period of study and reflection on the psychosocial approach of violence towards women in Brazil, through Feminist Theory, Intersectionality Theory, Critical Discourse Analysis, Social Psychology Criticism, Criminology Criticism, among others. Most of these approaches to our study show that violence against women is a diverse and complicated theme and that studies on it have limited efficiency. Our contribution tried to take this phenomenon from another angle, trying to understand the relation between singular experiences and the construction of reality that are offered by hegemonic discourses and generated alternatives.

The intervention in a Center for Reference and Assistance for Women who are victims of violence (CRM) — an integral institution of national prevention policy and the fight against violence towards women in Brazil, as we will see (Gonsalves and Gonçalves, 2016) — situated in Rio de Janeiro initially resulted in many concerns amongst its creators: we perceived the extreme vulnerability of women that live in the favelas of Rio whose lives are marked by constant violation of their rights, either by their (ex) significant others, drug traffickers that control the area where they live (Dowdney, 2003), or by the State and its agents there that can act in an extremely violent manner (Machado da Silva and Leite, 2008; Misse, 2002). Even though these CRM are relevant for the transformation through which many women pass, studies on the impact generated on the lives of those who use their services are scarce (Pougy, 2012).

Another motive for this investigation is the fact that, even though Brazil has a specific law against violence towards women, Maria da Penha Law (Law 11340/2006), the statistics continue to be alarming: the number of women murdered in the last 30 years in the country went up from 1,353 cases in 1980 to 4,762 cases in 2013 (Waiselfisz, 2015), with a total of 106,093 dead women in the country. The Institute for Public Safety (Teixeira y Pinto, 2014) concluded that, in 2013 in Rio de Janeiro, of $82.8 \%$ of the cases of violence reported to police, the victims were women; and of these cases, in $51.2 \%$ they were in close relation with the aggressor (a father, stepfather, another relative, or significant other). They affirm that, "during 2013, almost daily, women had their lives gravely threated by someone in their family household and some $(50 \%)$ lost their lives to this violence» (Teixeira and Pinto, 2014:58).

Maria da Penha Maia Fernandes is one of the many women who has suffered the effects of familial and domestic violence. Her life story is confused with those of the many who have the right to a life free of vio- 
lence constantly violated. She fought during 20 years for her aggressor - her ex-partner - to be condemned. She was abused by him for 6 years, suffering two attempts of murder, the first with a firearm and the second by electrocution and suffocation: the most evident result being that she is now an irreversible paraplegic. The case arrived at the Inter-American Commission of Human Rights of the Organization of American States (OAS) in 1998, and in the year 2001 Brazil was condemned for rights violations, failure to complete its obligations, negligence and omission according to the Convention of Belém do Pará, of which it is a signatory. In 2002, the aggressor was sentenced to complete 10 years in prison and, in the end, he only served 2 years. ${ }^{1}$ In 2004 , the Interministerial Working Group was created, coordinated by the Secretary of Special Politics for Women (SPM) - created in 2003 - and, together with a consortium of NGOs, they created a law proposal to combat violence against women (Pandjiarjian, 2006). On August 7, 2006, Law 11340/06 - Maria da Penha Law - was sanctioned and familial and domestic violence against woman became considered a felony.

According to surveys carried out in different countries, «between $10 \%$ and $69 \%$ of women indicate having been the object of physical aggression by a male partner at some moment of their life» (Krug, Dahlberg, Mercy, Swi and Lozano, 2002:18). Nevertheless, the people in more favored classes are able to camouflage the signs of abuse by looking for particular services and "paying» for silence from health professionals in order to circumvent the law (Ferreira, 2002). This under reporting of violence leads to an erroneous belief that this only happens in disfavored classes. Depending on the seriousness of the situation, we see in the press cases of famous people and the wealthy classes involved in violent relationships and even cases of murdered women. In Brazil, one well known case was of the journalist Pimenta Neves, who killed his ex-girlfriend because she had ended the relationship. August 20, 2000, the renown Brazilian journalist, director of the newspaper The State of São Paulo, shot his ex-girlfriend Sandra Gomide, also a journalist. Some days before, Pimenta Neves had threatened and hit Sandra, who reported the violence. The journalist was tried and was incarcerated for only 6 months, then he was considered a "person of respect, a good professional, good father, and good person» (Teles and Melo, 2003:12). It is important to note that the victim as well as the aggressor were middle class, of an elevated educational level, and white. At the time of the crime, the aggressor had not ingested any substances that could have altered his conscious: he commit- 
ted the crime because he could not accept the loss of his girlfriend; he could not accept his loss of power over her. Cases like this become well known because they involve people from favored social classes who have a high level of education, which, according to societal belief, would prohibit the use of violence. Unfortunately, what we see being endorsed through media with increased frequency, are cases of people from lower classes who turn to the public network of support.

\subsection{The Slums of Río de Janeiro}

One of the distinguishing features of the city of Río de Janeiro is the collection of immense favelas, or slums, that extend through diverse neighborhoods (almost all of them) of the city: almost $20 \%$ of the inhabitants of the city live in slums (IBGE, 2011). Stigmatized from the time of their origin, at the end of the 19th century, "their growth and development is confused with the history of Río de Janeiro itself» (Andreatta, 2005: 4) and they have an intimate relationship with the economic, social, political, cultural and spacial changes that pass through the city.

When talking about the slums, it's common to consider them all equal, as a great aggregation of houses and poor people. Nevertheless, they are a complex phenomenon, diverse and in constant mutation. One of the biggest slums of Río de Janeiro, the Complexo de Maré- or simply Maré-, is a conglomeration of 16 communities that occupy more than 4 $\mathrm{km}^{2}$, with an estimated population of more that 130 inhabitants, distributed in close to 40 thousand domiciles, representing $2.26 \%$ of the population of the city (Souza e Silva, Barbosa, Biteti and Fernandes, 2009; Varella, Bertazzo and

Berenstein Jacques, 2002). Currently, $51 \%$ of its inhabitants are women (IBGE, 2011). One of its greatest problems — and of the majority of the poor communities in Río de Janiero- is urban violence, principally due to the extensive presence of the trafficking of drugs, organized crime, and the scarcity of public security units. The communities that make it up are "controlled» by different gangs, that are in constant territorial disputes.

\subsection{Violence: What are we talking about?}

To fight, hit someone, assault, injure, kill, all of this can be considered violence: they are the distinct manifestations of the same social phenomenon, that is much more extensive than it seems. Riffiotis, using the ex- 
pression palabra-valija, or ...., to refer to this phenomenon, he affirms that violence is a "generic notion and homogenizer that covers different social phenomena" (1998:31). Multifaceted phenomenon, multidimensional and complex are also expressions used to define it (Buvinic, Morrison y Orlando, 2005; Krug et al., 2002; Misse, 2002). This palabra-valija encompasses and reconciles events that have in common the abuse of power, threat, the use of force, tensions, hierarchies, inequities, breaks of equilibrium, conflicts, intimidation. When presented, one can observe an imbalance of power, permanent or momentarily, that in general causes physical and psychological damage, many times irreversible. The many different forms of defining it, the naturalization of abuse, the unknown, the resistance from victims to report it, the lack of training for professions to identify the signs, government disinterest, are some of the factors that contribute to the frequent increase in its statistics (Azevedo and Guerra, 2006). In this study, we will concentrate on two forms of violence that frequently occur in Brazil: violence against women and urban violence.

In western countries, it has not been long that violence against women started to be considered a social problem. In the 1970s, the feminist movement — which for a long time has fought for the acknowledgement of women's rights - along with other women's groups and the United Nations pressured governments to create specific laws to confront the problem. This pressure served to give visibility to this type of violence that, despite being an ancient phenomenon, was restricted to the private world, or rather, it stayed trapped in the walls of a home: it was accepted, tolerated and socially approved (Soares, 1999). It is a problem that affects every country in the world and does not distinguish between social class, group, religion or culture.

In the favelas, urban violence manifests itself in three forms: 1 . The ostensive presence of drug traffic; 2 . Conflicts between the groups that lead the traffic; and 3. Political corruption and violence. Misse (2002) affirms that the association between territorial disputes of the armed groups that dominate the sale of drugs in Río de Janeiro and the corruption of pólice aggravate the problem of violence, and therefore, what occurs there becomes unique. Every day, those who lives in these spaces and live with this violent dynamic have to reorganize themselves in order to survive, adapting themselves to new configurations, to the new norms and rules, to the new owners of the favela (Dowdney, 2003). The "power» for the traffickers is often times legitimized by the people who live in the community fby a set of factors: they offer protection and maintenance of the order in the slums, support for development of local commerce and leisure activities. They also force the residents to keep a code of silence 
and to allow drug sales to happen in front of their homes. Whoever does not comply or agree to these terms will be punished with evictions, aggression or even death; it's a trade-off for naturalized tyranny (Santiago, Gonçalves and Peregrin, in press). We can say that what we find there is a forced reciprocity marked by a "double strategy of support and punitive violence for the non-compliant» (Dowdney, 2003: 46).

\subsection{National policy on the fight against violence against women in Brazil}

International legislation combined with the pressure of the feminist movement had an important role on the trajectory of the conquest of rights for women. It was the combined action of these social spheres that guaranteed it, for example, the creation of a legislation that seeks to eradicate violence against women. This combined effort has brought benefits to women in many areas. According to the Secretary of Policy for Women form the Brazilian government, the network of aide for women is composed of a group of institutions from different sectors - health, justice, safety, social assistance - that seek the expansion and qualification of assistance from an adequate and specialized perspective, the comprehensiveness and humanization of the services. Currently, they integrate a specialized network, specialized police precincts for assistance for women, health services, Family and Domestic Violence Courts, reference centers and shelters for women. The CRM are essential institutions of the National Policy on the Fight against Violence Against Women and hope to promote a break in the cycle of violence and the (re)constructions of the feminine citizenship through global actions and interdisciplinary care (Gonsalves y Gonçalves, 2016;SPM, 2006). Article 35 of the LMP gives incentive for the creation and promotion. Currently there exists close to 238 CRM in all of Brazil, 35 in the province of Río de Janeiro and 4 in the capital of the province ${ }^{2}$.

The reference center where this study took place is an extension program of the Federal University of Río de Janeiro (UFRJ), located in the Maré Complex. It is composed of a multi-profressional team that consists of psychologists, social workers, lawyers, educators, and practicum students from different disciplines. It offers psychological care, social and legal advice, and workshops and educational and vocational classes. The women arrive by spontaneous requests or through other services in the network [de enfrentamiento].

2. https://sistema3.planalto.gov.br/spmu/atendimento/atendimento_mulher.php? uf=RJ 
The general objective of this investigation was to deepen the knowledge about the psychological reality of women that suffer violence, that live in violent contexts and that frequent a Special Care Center. We search to understand the peculiar trajectories for the definition of the condition of being a woman that suffers violence in a Río slum. We hope to understand and translate this social reality through intersected voices that construct a collective discourse, with different focuses and interpretations about shared life experiences (Pujadas, 2002); in conclusion, to understand how violence against women assigns and reassigns meaning to itself in the context of urban violence.

\section{Methodology}

Some tools were used in order to help us acheive our objectives: Participant Observation (PO) (Valladares, 2007), Life Histories (LH) (Rizzini, Castro and Sartor, 1999) and Discourse Analysys from the biographical-narrative approach (Bolívar, Domingo and Fernández, 2001; Pujadas, 2002). In order to arrive at a deep understanding of women who frequent the services of these Care Centers, we believe that the most appropriate thing to do is use qualitative methods that value the subjectivity of the subjects and the construction of the social reality that they share. Women who frequent these centers and live with the violence present in the slums were interviewed. The interviews were translated and transcribed for later analysis, divided into three parts, as we will see later.

\subsection{Interviews}

The semi-scripted interview was based on participant observation and previous bibliographical consults centered on themes such as the different forms of violence that affect women, violence areas and the favelas, the public policies and legislation that fight against violence. We divide the script into 3 large sections. 1 . Self-introduction; 2 . The Domestic realm and gender violence; 3 . The public sphere and urban violence.

The process of realizing these biographical-narrative interviews was carried out between January and February of 2011 at the studied Care Center and were an average of 2 hours in length. The selection was random, respecting the condition that they had been using the center for at least one year, participating in any activity offered there, group or individual. It was explained that the purpose of the interview was to give a 
voice to women in order to know their life stories, since that knowledge they had was not familiar to the researchers.

The fact that the interviewees previously knew the investigator/interviewer was a facilitator for the study, since a trusting and empathetic relationship had already been established — constructed previously while the interviewer worked as a psychologist at the center-, essential characteristics in order to conduct a participant observation and life history interview (Rizzini, Castro and Sartor, 1999; Valladares, 2007).

\subsection{Analysis}

In the first stage of analysis we conducted a brief survey of the interviews - the first contact with the collected material — as indicated by Wetherell and Potter (1996), in which they analyzed the raw results, to find significant and valid points for future interpretation (Bardin, 2011). In the second phase, we group the collected information into 5 thematic blocks that represent common characteristics and that in some way answer the investigators questions. The third and final stage consisted of the proper analysis. In order to understand that the highlighted themes incorporate themselves in the interviews as much as real life, we did a cross between them in order to develop our analytical categories. In general, the contents from the grouped themes intersect, or rather, crisscross in the discourses of the women; this intersection is in itself the condition of emergency for women and understanding of varied faces of a prismatic reality. All the categories, consequently, are composed of crossing the thematic groups and their central themes to attempt to answer our questions, doubts and objectives.

\subsection{Participants}

While the interviews were taking place, one of the participants asked to be called Girasol (Sunflower), because she had been advised that her identity would be preserved. From this point, we opted to call all the women with flower names. As such, for this investigation we have 10 participants in this «garden» of stories: Begonia, Magnolia, Amapola (Poppy), Iris, Azucena (Lily), Acacia, Azalea, Girasol, Jazmín (Jasmine), and Hortensia (Hydrangea). They are from different parts of Brazil, but they have lived for many years in Río de Janeiro and more than 10 years in the Maré Complex. The majority are Catholic (5) and Evangelist (3), as it is in all of Brazil. They perform traditionally feminine activities: farmers, cooks, 
seamstresses, artisans, housewives, cleaners, and nannies. Only 2 are separated, 6 have a civil or religious marriage, and 2 are in a domestic partnership. The principal traits that are common to all the life stories analyzed are life in Maré, the violence they suffered over their length of their lives, poverty and maternity, since all of them are mothers.

Other common traits that can be highlight are: 1 . Virginity as a form of access to marriage, since in Brazil it was common that if a single woman lost her virginity she would marry to repair the «damage»; 2 . The low level of education related to the early entrance on the job market to help support the family income; 3 . All of them left their job after their children were born; 4. Life in Maré and the common complaint of all of them, the presence and coexistence of drug trafficking that affects many levels of their lives.

\section{Discussion or possible analyses}

In this investigation, we try to understand the psychosocial reality of women who suffer gender violence, that live in violent contexts and that frequent the Center of Specialized Care, through the telling of their life stories. We wish to understand and translate this social reality through the various voices, through the intersecting voices that construct a collective discourse, with different focuses and interpretations about shared experiences (Pujadas, 2002); in sum, how gender violence is (re)signified in contexts of urban violence. The biographical narratives seek to break the rigidity of the structured interviews and the result brings to light the shared experiences and societal structures that shape these women (Weller, 2009). With this, more than understanding what is being narrated, it is possible to understand how this narrative is being constructed. It is in this direction that we developed our analysis: to know what they say about determined themes and to understand in what manner these individual narratives relate with others, how they complement each other and how they (re) construct themselves through these specific social conditions. Further on we will present our principle findings.

\subsection{Women of Maré}

From the analysis, we can affirm that the women who seek out services are not inert; they are not passive victims of violence and they found different ways to cope, support and overcome the violence suffered, as Magnolia, Iris, Jazmín and Hortensia, who believe in the punishment of 
the aggressors, support other women and confront suffered violence with other forms of violence:

Interviewer (E).- ¿ What has to happen to these men who abuse women?

Magnolia._- Punishment.

E.-What sort of punishment would you give them?

Magnolia.- Arrest. Ah, I believe that if they would let me I would hit him too so that he does not hit a defenseless creature... because there are many women who also abuse men [emphaisis mine]

E.- Do you support women who come forward?

Iris.- Of course, I say «Go, woman» Go make the report». The problem, you already know what it is, is to live with the abuse ${ }^{3}$.

Jazmín. - I grabbed, my daughter, I was not going to do it, you know... then I grabbed the rolling pin and «pow!» He was lucky because I hit here, if it were in the face.... I attacked but it was because he assaulted me... and so I told him, "you do not do this to anyone...» it was the only time that he raised a hand to me... (married, 21 years) ${ }^{4}$.

Hortensia.- - Our last fight I almost killed him. I did not kill him because he ran. E.-What were you going to do?

Hortensia.- I was going to stab him with the knife ${ }^{5}$.

Vulnerability and incapacity of liberating oneself from a violent relationship were, for much of the time, descriptors of women who found themselves in this situation. Santos and Izumino(2005) criticize the simplicity from a feminist approach that traps women in the condition of being only victims of gender violence. Sagot (2000) equally criticizes what she usually affirms in respect to these women; for the author, many of them do not passively live through the suffered aggressions. Soares (2009)

3. E.- Você apoia mulheres que denunciam?

Iris.- Com certeza, eu falo "Vai atrás, mulher. Vai, denuncia mesmo». O ruim, sabe o que é,é você conviver apanhando.

4. Jazmin.-Peguei, minha filha, não ia fazer isso não, sabe... aí peguei aquele rolo de pastel, nessa época eu fazia massa de pastel. Aí peguei o pastel e pá! E só deu sorte porque pegou aqui, pegasse na cara... Eu taquei mas foi porque me agrediu, né... ai eu falei assim, "isso não se faz com ninguém..." foi a única vez que ele levantou a mão pra mim...

5. Hortensia.- A última briga da gente eu quase matei ele. Só não matei ele porque ele correu.

E.-Que você ia fazer?

Hortensia.-Eu ia furar ele com a faca. 
also criticizes the reproduction of the imaginary constructs around men and women: the first are seen as dominators and violent and the second as passive and victimized. For this author, the form of analyzing violence against women, supposing that this binary logic would always be unilateral, reduces the problem and crystalizes the placement of victim and aggressor, as if there were other possibilities for both in society and their relations. Zurita Márquez (2012: 19) notes that this simplification that Sagot (2000) and Soares (2009) talk about, reinforces the framework that «male by being male abuses and woman, being women, is victim of this violence», disregards important aspects, such as, for example, why do some men socialized under the same culture, society and gender models commit acts of violence and others no.

In our first category - Women of Maré-, we find something that approaches what these authors claim (Sagot, 2000; Santos and Izumino, 2005; Soares, 2009; Zurita Márquez, 2012): the women are not always passive victims of violence and find ways of coping, supporting, and overcoming - in their way - the problem, even though they do not always recognize it right away. Through the analysis, we can assert that our interviewees live relations where marital aggressions are, in greater or lesser extent, reciprocal. We do not find only fragility as could be expected from representations and stigmatized discourses about women that are immersed in a violent relation. On the contrary, we find certain forms of fighting against the violence.

\subsection{Violent territory?}

In general, the first nouns that come to our heads when we talk about the favelas of Rio are violence, illegality, disorder, and lack (Machado da Silva and Leite, 2008; Souza and Silva et al., 2009; Valladares, 2005). Wacquant (2006), who analyzes poor French neighborhoods and American ghettos, claims that any metropolis has at least some residential concentration of lower class inhabitants viewed in the same stigmatized form as the slums of Río de Janeiro are seen. An aspect of important relevance in the narratives of the women refers to the urban violence experiences in the territory: it impacts personal daily activity, to the extent that it alters their routines, actions and decisions. To live in the Maré Complex is a singular experience, principally because of the heavily armed youth, as Azalea and Hortensia tell: 
Azalea.- This is not a bad place to live. If you get rid of the drug traffic, in this case it would be a wonderful place, because there are busses everywhere. But with the drug traffic you can't, because you have to be, so careful all of the time, because if not you end up giving in to the drug traffic. They try to buy you in every way ${ }^{6}$.

Hortensia.- It's a place controlled by others and you are not free. You leave and don't know if you can come back to your own house. We have our houses and at the same time we don't, because if they have to throw you out they will through you out ${ }^{7}$.

Fear is the main trait in common between the collected narratives in this respect. As we see in the second category - Violent Territory? - for the women who look for the services there is no other option but to keep living in the favela. One of the participants- Acacia- tells us that the strategy to survive is «see, hear and keep quiet», keeping the norms imposed by the drug traffickers.

E.- And you said that your house now keeps the door close... What are the strategies to avoid problems here?

Acacia.- See, hear and keep quiet! ${ }^{8}$

In this context, the drug traffic occupies an ambiguous and contradictory place, on one side it guarantees the resolution of public and private conflicts and on the other hand it determines behaviors. In the areas of the slum considered "areas of risk", the drug traffic with its norms and its own laws - many extremely violent- converts itself into one of the only places of help, since the State is absent in these spaces, as stated by Magnolia and Acacia:

Magnolia.- Here among them are our police. ${ }^{9}$

6. Azalea.-Aqui não é um lugar ruim de se morar. Se acabasse o tráfico, aqui seria um lugar ótimo, porque tem ônibus pra tudo quanto é canto, né? Mas com o tráfico não dá, porque você tem que estar, assim, tomando cuidado a todo momento, senão você acaba se entregando ao tráfico. Eles procura te comprar de tudo quanto é forma.

7. Hortensia.-É um local que é comandado pelos outro e você não tem liberdade. Você sai e não sabe se pode entrar na sua própria casa. E a gente tem nossa casa e ao mesmo tempo não tem, porque se eles tiver de botar pra fora eles vão botar.

8. E.- E a senhora falou que a sua casa agora mantém a porta fechada... quais são as estratégias pra evitar os problemas aqui?

Acacia.- Ver, ouvir e calar!

9. Magnolia.- Aqui dentro eles são nossa polícia. 
Acacia.- Look at me... I am not for the «boys», no, but many times the police are worse than them! ${ }^{10}$

Yes, Mare is a violent area. But the cause is not the actual conflicts, but the historically rare attention from the State to the inhabitants of these areas and their extremely violent interventions and infringement on their rights. Something present from the establishment of the first Río slums, what we find today is the result of structural and State violence, either by negligence in offering basic services and guaranteeing fundamental rights or by excessive presence in police action. It is a violence directed towards the poor, towards the black, towards women, that stigmatizes, segregates, and from a greater and former evil converts into victims, that should be opposed.

\subsection{Violence(s)}

There are infinite forms of violence and rights violations that women in the slums of Río de Janeiro can suffer. From the interviews, we can identity two specific forms of violence that were prominent in the analyzed narratives: violence against women and urban violence; like we see in the sections of the interviews of Azucena and Magnolia:

Azucena.- He slapped me and hurt my eyes, which even left me defective on that side of my vision ${ }^{11}$.

Magnolia.- Here it is very violent, the violence here is not only seen. Even seeing groups pass... Every big arm! We pass in between them. It doesn't stop being violence to us ${ }^{12}$.

In the third category - Violence(s) — we did not intend to identity a new typology or different definition from those that exist, but to amplify them, including in these, particularities and intersectionalities that influence the comprehension and the form of living and confronting violence in a determined social context. Urban violence, as we saw before, is that which limits circulation and freedom, imposes rules and norms of conduct,

10. Acacia.- Olha eu... eu não sou a favor dos «meninos» não, mas a polícia muitas vezes é pior do que eles!

11. Azucena.-Ele me deu um tapa que feriu meus olhos, fiquei até com defeito nesse lado da vista.

12. Magnolia.- Aqui é muito violento, a violência daqui não é só você assistir. Só em você ver os comboios que passam, cada armão! A gente passa aqui no meio deles. Não deixa de ser uma violência a nós mesmo. 
implants fear and insecurity, intimidates, frightens and coerces. And as Begonia says, «it affects everyone, those who live in Maré and those who live outside»:

Begonia.- Not only mine [my life], everyone's, all the people, those who live here and those who live outside. The violence is not only for the people who live here, it's for everyone ${ }^{13}$.

In relation to violence against women, different from what you would imagine, it is not only physical aggressions that characterize this violence for the participants, as Acacia and Hortensia tell us:

E.- You never suffered physical aggression, but, did you suffer other types of aggression?

Acacia.- - Sexually. He had to do it! And today... morning was coming. Sometimes I cried. So what desire did I have? It was terrible. It wasn't easy ${ }^{14}$.

Hortensia.- She submits to my brother in law, she's humiliated. He has other women, stays with them for 3 or 4 months. And she's there. Then, when it doesn't work with the others and he wants to return, she accepts ${ }^{15}$.

In addition to the best known and most visible form of violence - physical violence - the participants tell that they also suffer humiliations, rape, betrayals, insults and injuries, harsh words, shouts, the husband who spends everything on drinks. In many of the narratives, alcohol is associated with violence. Begonia asserts that this violence is very sad, and Amapola agrees with the sadness of the situation, principally for women who do not work and are dependent on their partners. Magnolia and Hortensia include in what they consider to be violence having to accept the lovers of their partners, and say that many women are still obligated to accept such a situation, that generally can become public and almost official. The popular expression «I will not be happy because I have a husband» reflects what Amapola and Azalea say about violence and

13. Begonia.-A minha [vida] só não, de todo mundo né, de todo mundo, quem mora aqui e quem vem la de fora. A violencia não é só pra gente que mora aqui não, é pra todo mundo. 14. E.- A senhora nunca sofreu nenhuma agressão física, mas sofreu outro tipo de agressão? Acacia.- Sexualmente. Tinha que ser! É hoje... chegava de madrugada. As vezes eu chorava. Então que disposição que eu tinha? Foi terrível! Não é fácil.

15. Hortensia.- Aí ela fica ai se assujeitando ao meu cunhado, sendo humilhada. Ele arruma mulher, fica três, quatro meses com outra mulher. E ela ali. Aí quando aquela não dá certo, ele quer voltar, ela aceita. 
infidelity in matrimony and its legitimization. Even though many forms of violence exist in a relationship, it is better to stay married.

There are factors that make women stay in violent relationships. We identify principally: the inequalities in gender relations, financial dependence, the naturalization of violence, fear and low self-esteem, cultural and religious norms and the patriarchy, as we see in the stories from Azalea and Girasol:

Azalea.- Because sometimes the person withstands because the house is his or she doesn't work ${ }^{16}$.

Girasol.- When a women does not have a job, she does not have independence. She believes that she will be hungry, needy... Where will she live? ${ }^{17}$

Hortensia's life story, while still having two children who depend on her, exemplifies staying in a relationship that she says she is fed up with:

Hortensia.- Do you know what it's like to live in a place when you have no other place to go? That is my case.

E.- Do you believe that you have no other option?

Hortensia.- I don't have a choice. Why? I have a fixed income to pay rent with. So that for me to leave the house with two kids... only the two that depend of me still. So I cannot take them to a life of sacrifice when they already have all that they want at home. So I keep buying time until they grow up, in order to determine my life. Determine what to do, if I am going to live alone or if... but keeping up this routine, I'm tired ${ }^{18}$.

The set of factors that brings them to live and stay in these relations can be explained by Intersectionality Theory, which notes how different forms of oppression intertwine converging in specific situations of social inequality. Nogueira (2012: 62) states that «the classical models of under-

16. Azalea.- Porque às vezes a pessoa atura porque a casa é dele ou não trabalha.

17. Girasol.-Quando a mulher não tem um trabalho, não tem independência. Pensa que vai passar fome, necessidade... vai morar onde?

18. Hortensia.- Sabe aquela coisa de você viver em um local quando você nem tem aquela opção pra onde ir? Assim é meu caso.

E.- Você acha que não tem opção?

Hortensia.- Eu não tenho uma opção, por quê? Então, eu não tenho salário fixo pra mim poder apagar um aluguel. Então pra mim sair de casa com duas crianças... E só os dois que dependem de mim ainda. Então não vo levar eles pra uma vida de sacrifício sendo que eles tem dentro de casa tudo que eles querem. Então eu vo empurrando com a barriga até eles crescer pra eu poder dar uma «difinada" na minha vida. "Difinir» o quê que vo fazer da minha, se eu vo morar sozinha ou se eu... mas continuar a rotina que eu to, cansei. 
standing the phenomena of oppression in a society, like the most common, based on sex/gender, on racelethnicity, on class, on religion, on nationality, on sexual orientation or in the deficiency, do not work independently one from the other.» The factors announced by the author, associated with the fact that they live in a violent area, contribute to the emergency of domestic and familiar violence against women in Maré. We can say that our participants were/are victims - at least on one occasion or their lives - of different forms of violence, and especially, violence against women. Nevertheless, the non-victimist discourse, that on many occasions these women present, contradicts some of the privileged elements with respect to the classic theory. It is worth it to point out that the CRM had an important influence on the way in which these women now perceive violence. Resorting to this service allowed them to start denaturalizing violence against women and helped in similar situations. From here, it impregnated their everyday life in little crossroads where an alternative response —non-submissive and non-victimist— were possible.

\subsection{Confronting the violence}

In the fourth section - Confronting violence- we see that for the participants the best option to confront the violence that they suffer in their homes is to seek out a Center of Care; this choice explains itself in part because there is a discord between the expectations of the women and what is offered by the police, the justice system and the traffickers, as Girasol, Hortensia, and Acacia tell us respectively:

\footnotetext{
E.- If you had to ask for help from someone here, would you ask the police or call the traffickers?

Girasol.- I would think it over twice before making a decision, but... between the police and the drug traffickers, I would call the traffickers.

E.- Do they help more or can they help more than the police?

Girasol.- They live with us more, they know the problems in the community... the police don't ${ }^{19}$.
}

19. E.-: Se você tivesse que pedir ajuda pra alguém aqui dentro, você pediria à polícia ou chamaria os meninos?

Girasol,-Eu ia pensar duas vezes antes de tomar qualquer tipo de decisão, mas... entre a polícia e os menino, eu chamaria os meninos.

E.-Eles ajudam mais ou podem ajudar mais que a polícia?

Girasol.-Eles convivem mais com a gente, eles conhecem os problemas da comunidade... os polícias não. 
Hortensia.- Justice is very slow. By the time it gets resolved, the person has already been long dead ${ }^{20}$.

Acacia.- Look, its not an advantage. You owe them a favor.

E.- And it's not good to owe them a favor, right?

Acacia.- No, no. It's better to pray the Our Father than ask them for something $^{21}$.

Another motive for this choice is the lack of credibility in formal justice and the police security carried out in the favelas of Río. This delivers results, in many cases, with humiliating experiences, reproachable behavior from the police, inadequate laws, and slow and inefficient proceedings. What women are looking for is the end of the aggressions without having to separate themselves from their partners and without them being criminalized or imprisoned. What current legislation offers - criminalization and punishment of the aggressor - is the opposite of what many women hope for (Muniz, 1996), that essentially what they call for is an end to the daily violence in their homes.

Associated with this we have the implicit social culture in the presence of drug trafficking, even for resolving personal problems. One of the strategies used by those living in these areas to solve their problems is known as desenrolo, or unroll (Santiago, Gonçalves y Peregrin, in press). The expression desenrolo, in the vocabulary of the favela, refers to a form of negotiation of conflicts between different social agents, functioning as an alternative mechanism of serving justice. Through the mediation of the trafficking gangs they look for a solution to individual and private problems that official and legal methods do not managed to resolve. This strategy can be considered a form of legal pluralism, that Sousa Santos (1987) describes as a situation where "in the same geopolitical space (officially or no) more than one legal authority co-exist," this is, the official and other possible forms carried out by institutions and persons that occupy, in some form, the place of the State. The women living in the favelas also use this recourse to solve their marital problems, basing them in one of the commandments of the traffic, which prohibits hitting or raping women within the limits of the favela (Farias, 2008). Nevertheless, the desenrolo has its price, as the participants indicate:

20. Hortensia.- A justiça ela é muito lenta. Até eles chegar a resolver, aquela pessoa já morreu há muito tempo.

21. Acacia.- Olha, vantagem não é. Que fica devendo favor.

E.-E não é legal dever favor a eles, né?

Acacia.- Não, não. É melhor você rezar um Pai Nosso do que pedir alguma coisa. 
E.- Would you ask them for help for anything?

Hortensia.- Never. It could be the worst thing in the world, but I wouldn't ask any of them for help. Because if you ask for help you are always owing. When they arrive at your door you have to pay them ${ }^{22}$.

The women who suffer violence from their partners in the favelas have the option to file a report of resort to one of the boys from the drug traffic. These choices bring different consequences: on one side, the women can be discredited, and as such they do not ensure that the police, devoid of appropriate sensitivity, protect them, and on the other hand, they start to owe favors to the drug traffickers. Even so, gaining access to the traffic and its laws - the alternative norm expressed by Sousa Santos (1987) — is among the principal possibilities commented on by the inhabitants of Maré:

E.- And the women who have problems with their husbands, do they look for them?

Azucena.- Whoever asks knowns what it is that they're going to do.

E.-What are they going to do?

Azucena.- First off, a beating...

E.- To the husband?

Azucena.- - To the husband. First a beating that will leave him with everything broken. Second, if it happens again, they kill him. He didn't respect... [the laws of the traffic $]^{23}$

E.- And if you had problema, who would solve it? The police or them?

Azalea.- Ah, our law here is them. The police when they come here lose their lives ${ }^{24}$.

In the favela, we witness the intervention of the Government, that prioritizes the fight against urban violence - in an extremely hard and

22. E.- Você pediria ajuda pra eles, de alguma coisa?

Hortensia.- Nunca. Podia ser a pior coisa do mundo mas eu não pediria ajuda a nenhum deles. Porque se você pedir ajuda você fica sempre devendo. Quando chegar na tua porta você tem que pagar.

23. E.-E as mulheres que têm problemas com os maridos procuram eles?

Azucena.- A que procura sabe que eles vão fazer.

E.- O que eles vão fazer?

Azucena.- Primeiro da uma coça...

E.- No marido?

Azucena.- No marido, primeiro da uma coça e fica todo quebrado. Mas a segunda vez, se repetir de novo matam. Não tá respeitando... [a lei do tráfico].

24. E.-E se tivesse algum problema, quem revolve? A polícia ou eles?

Azalea.- Ah, a lei nossa aqui é eles. Polícia quando entra aqui perde vida. 
aggressive manner, without measuring the consequences- and that forgets about domestic and familial violence. In this context, we see that violence against women resignifies itself to emerge in a context admittedly violent. In order to confront this form of violence towards women that covers exceptional nuances, one needs to develop strategies that consider the particularities imposed by the norm. Meanwhile, what we see if, on one hand, the official strategies, composed by the CRM, police and judicial intervention; and on the other hand, the unofficial strategy offered by the drug traffickers. We observe that, in the favelas of Río, extreme situations arise, where ending a violent relationship converts itself into something virtually impossible through legal routes. Gender domination, the omission of the State and the presence of the drug traffic do not allow for a life free of violence, and neither do they provide ways for women to break the domination.

\subsection{The Women's House}

Nevertheless, in our last category — The Women's House-, we see that there is an appropriation for the CRM, equipment of the national policy of the confrontation of violence against women, that does not happen in other places, as much in the field of gender as well as the public social policies in general. The service is considered by its users as a place where they have free access, they are welcome and their demands and opinions are heard and taken into account, as Jazmín, Begonia, Amapola and Azucena point out:

Jazmín.- Then, when we are weak, we need to have support... and our support is you, our center here...that receives us, tells the path we have to follow ${ }^{25}$.

E.- And what do you think of the Center?

Begonia.- For me its good, this house here is the best. Not only for me, for every woman who frequents $i \mathrm{i}^{26}$.

25. Jazmín.- Então quando a gente é fraca assim, a gente tem que ter um apoio... e o apoio são vocês, no nosso Centro aquí... que acolhe, fala o caminho que tem que seguir. 26. E.-É o que, que a senhora acha do Centro?

Begonia.- Ah, pra mim é uma boa, essa casa aqui é tudo de bom. Não é só pra mim não, pra todas as mulheres que vem pra ca. 
Amapola.- I like it a lot here, being here. Sometimes, when you do not come, I miss you ${ }^{27}$.

E.- How is the Reference Center? What do you think of it?

Azucena.- A A , I think its all good here, my dear! All the best! I'm not telling that I don't leave here! You don't find me here every day. [...] I feel good here, they treat me well. Thanks to God, My God! God gave me this house! ${ }^{28}$.

There exists and appropriation of space: it is a public policy that has effectively taken on a life of its own. Aside from providing quality monitoring, it is worth highlighting that the care removes itself from any logic of criminalization and prosecution of the personal relationships. Supporting and respecting the decisions of the women is fundamental so that they construct a trusting relationship between the women and the professional/institution. They do not obligate or encourage the women to file a police report, nor do they insist that they break of their relationship with the aggressor as a prerequisite to receive services from the Center. More than confronting the existing problem, the perspective that the preventative enroots in their everyday lives is the best strategy for intervention realized in this center.

For the women, who use a comparative criterion to evaluate the service, everything is perfect, since the other public policies to which they have access - health, education, assistance, security - are precarious and inefficient. The Center is far from being as efficient as the women have declared, but their assessment is relative and we should have this in mind so that we do not get carried away by the positivity.

An important caution that one must have in the intervention with these women is related to the (re)victimization and the emancipation of those who look for this service. There is a subtle limit between the possibilities of intervention, and many times the professionals do not perceive that they can be producing or reinforcing the role of victim in place of helping the women overcome this condition. Is there a difference between saying to a woman: "you are married to a man who abuses you, so you are a victim of violence» or "you are married to a man who abuses you,

27. Amapola.-Eu gosto muito daqui, de ta aqui. Às vezes quando vocês não vem, eu sinto falta.

28. E.- Como é o Centro de Referencia, o que a senhora acha daqui?

Azucena.- Ah, eu acho daqui tudo de bom, minha filha! Tudo de bom! Não to falando pra você que eu não saio daqui de dentro! Vocês não vem eu todo santo dia aqui?! [...] Aqui que eu me sinto bem, tem vocês que ligam, que me tratam bem. Graças a Deus, meu Deus! Que Deus me deu essa casa! 
but you have the right to a life free of violence»? Are the professionals those that should tell the woman that she is a victim, or should the professionals explain what they consider violence and leave the woman to come to her own conclusion she is living in a relationship in which abuse is present? The danger is in negating the autonomy of the women in violent situations and producing another form of violence, institutional violence, inducing them to follow paths based on value systems that are not their own and are those of the professionals or the Center. To support, respect, orient, and generate a new shared knowledge, considering the particularities of each case and its context, is the first step for living a feminine citizenship to its fullest. The strengthening of women goes from the offering of emotional support, to giving them information about their rights and the legal processes, and supporting their decisions, even though these can be in opposition, in one way or another, to the institutional philosophy.

\section{Conclusions}

First we would like to highlight the need to acknowledge that the confrontation of violence(s) does not occur in a quick or simple form: an integral response is needed from a precise diagnosis of the phenomenon, that considers all of its peculiarities. In parallel, we find the need to denature reductionist gender categories/roles that trap as many women as men - the first always seen as passive victims and the second always considers as unconditional aggressors-, perceiving as such the violence as a relational phenomenon: we must flee from the essentialisms, generalisms, and facilitating dualisms.

We also need to propose policies that keep in mind the different demands of different publics, trying to understand the form in which many discriminations intersect and affect the many life stories.

We must invest in primary, secondary, and tertiary prevention policies, without only prioritizing the criminalization and prosecution, avoiding new rights violations. Violence, being a complex and multidimensional phenomenon, needs its confrontation to be realized through a group of different yet associated strategies: awareness, repressive measures, preventative measures, legal measures, projects and preventative and educative campaigns, rehabilitation and reintegration of the aggressors, information, support and orientation for the victims, casualty reduction. As such, we need to invest in public policies of confrontation to violence that move away from the criminalization / prosecution / victimization tripod, for the 
inhabitants of the favelas to not have to resort to the drug traffic in order to guarantee their constitutional right to life free of violence.

In particular, in regards to the policies of confrontation and to the services of care for women, there is a need to invest in the daily and continuing education of the professionals so that they act in a manner that respects the users of these public policies, keeping in mind and valuing their strategies and offering a collective construction of the future alternatives without impositions of hegemonic wisdom. Principally, it is needed to strengthen, amplify, train and inform the existing network of services so that they contribute to the confrontation of violence against women.

We must propose integral policies where we see that integrality is not guaranteed; to bet on forms of confrontation that do no convert themselves into violence; to consider the perception, choices and decisions of every woman on their lives; to avoid the production of the women-victims and to promote the development of autonomous women and citizens; to recognize that the women - not only the ones who live in the favelasfind themselves in a situation of particular vulnerability, the product of a set of associated inequalities; and in the case that there is not integral understanding of the situation in which they find themselves, the reduction of violence and inequality will not be achieved.

\section{Bibliography}

Andreatta, V. (2005). Favela-Bairro, un nuevo paradigma de urbanización para asentamientos informales. Cuadernos Internacionales de Tecnología para el Desarrollo Humano, 3. In http://omu.caf.com/media/32473/favela-bairro-paradigma-urbanización.- \%20 andreatta\%20verena.pdf. Accessed February15, 2013.

Azevedo, M.A. and Guerra, V.N.A. (2006). Violência doméstica contra crianças e adolescentes: um cenário em desconstrução. In Direitos negados: a violência contra a criança e o adolescente no Brasil. Unicef, Ed. Brasília. En http://www.unicef.org/brazil/pt/Cap_01. pdf. Accessed October 25, 2012.

Bardin, L. (2011). Análise de conteúdo. São Paulo: Edições 70.

Bolívar, A.; Domingo, J. and Fernández, M. (2001). La investigación biográfico-narrativa en educación. Enfoque y metodología. Madrid: Editorial La Muralla.

Buvinic, M.; Morrison, A. and Orlando, M.B. (2005), Violencia, crimen y desarrollo social en América Latina y El Caribe. Papeles de Población, 43: 167-214. En http://redalyc. uaemex.mx/pdf/112/11204309.pdf. Accessed November 30, 2014.

Dowdney, L. (2003). Crianças no tráfico. Um estudo de caso de crianças em violência armada organizada no Rio de Janeiro. Rio de Janeiro: 7Letras. 
Farias, J. (2008). Da asfixia: reflexões sobre a atuação do tráfico de drogas nas favelas cariocas. In Vida sob cerco - violência e rotina nas favelas do Rio de Janeiro. L.A. Machado da Silva, Ed. Rio de Janeiro: Nova Fronteira.

Ferreira, K.M.M. (2002). Violência doméstica / intrafamiliar contra crianças e adolescentes — nossa realidade. In Violência doméstica contra a criança e o adolescente. L.M.P. Silva, Ed. Recife: Edupe.

Gonsalves, E.N. and Gonçalves, H.S. (2016). A Prática profissional de psicólogas junto a um centro especializado de atendimento à mulher. En Experiências em Psicologia e Políticas Públicas. Conselho Regional de Psicologia do Rio de Janeiro (CRP 05). Caderno Anual, 8.

Instituto Brasileiro de Geografia e Estatística - IBGE (2011). Censo demográfico 2010. Aglomerados subnormais. Primeiros Resultados. Rio de Janeiro: IBGE.

Krug, E.G.; Dahlberg, L.L.; Mercy, J.A.; Zwi, A.B. and Lozano, R. (2002). Informe mundial sobre la violencia y la salud. Washington, D.C.: Organización Panamericana de la Salud, Oficina Regional para las Américas de la Organización Mundial de la Salud. En http:// mayores.pre.cti.csic.es/documentos/documentos/oms-informeviolencia-01.pdf. Accessed March 4, 2012.

Machado da Silva, L.A. and Leite, M.S.P. (2008). Violência, crime e polícia: o que os favelados dizem quando falam desses temas? In Vida sob cerco: violência e rotina nas favelas do Rio de Janeiro. L.A. Machado da Silva, Ed. Rio de Janeiro: Nova Fronteira.

Misse, M. (2002). Violência: o que foi que aconteceu? Jornal do SINTURF, 17(529). In http://necvu.tempsite.ws/arquivos/Violênciaoquefoiqueaconteceu.pdf. Accessed June 10, 2013.

Muniz, J. (1996). Os direitos dos outros e os outros direitos: um estudo sobre a negociação de conflitos nas DEAMs/RJ. In Violência e Política no Rio de Janeiro. L.S. Soares et al., Eds. Rio de Janeiro: Relume Dumará/ISER.

Nogueira, C. (2012). O gênero na Psicologia Social e as teorias feministas: dois caminhos entrecruzados. In Gênero, Psicologia, História. F.T. Portugal and A.M. Jacó-Vilela, Orgs. Faperj/Nau.

Pandjiarjian, V. (2006). Balanço de 25 anos da legislação sobre a violência contra as mulheres no Brasil. En Vinte e cinco anos de respostas brasileiras em violência contra a mulher: Alcances e Limites. C.S.G. Diniz; L.P. Silveira y L.A.L. Mirim, Eds. Coletivo Feminista. In http://www.cfh.ufsc.br/ levis/visrj.htm.

Pougy, L.G. (2012). Referências teóricas necessárias à intervenção com mulheres que sofrem violência. Revista da EMERJ, 15(57): 155-172 (Edição Especial). In http://www.emerj. rj.gov.br/revistaemerj_online/edicoes/revista57/revista57_155.pdf.

Pujadas, J.J. (2002). El método biográfico: el uso de las historias de vida en ciencias sociales. Madrid: Centro de Investigaciones Sociológicas.

Riffiotis, T. (1998). Dilemas Éticos no Campo da Violência. Comunicação \& Educação, 13 : 26-32. In www.cfh.ufsc.br/nucleosdepesquisdraivdraiva.htm. Accessed March 28, 2012. Rizzini, I.; Castro, M.R. and Sartor, C.S.D (1999). Pesquisando... Guia de Metodologias de Pesquisa para Programas Sociais. Rio de Janeiro: USU Ed.Universitaria. 
Sagot, M. (2000). Ruta crítica de las mujeres afectadas por la violencia intrafamiliar en América Latina: estudios de caso de diez países. Washington, DC: OPS. In http://www. paho.org/hq/dmdocuments/2011/GDR-Violencia-Domestica-Ruta-Critica-2011.pdf. Accessed April, 19, 2013.

Santiago, M.A.; Gonçalves, H.S. and Peregrin, F.M.M (in press). Entre a Lei Maria da Penha e o desenrolo: alternativas possíveis. In Psicologia, Tecnologia e Sociedade: controversias metodológicas e conceituais para uma análise das práticas de subjetivação. A. Arruda, Org.

Santos, C.M. e Izumino, W. P. (2005). Violência contra as Mulheres e Violência de Gênero: Notas sobre Estudos Feministas no Brasil. Revista Estudios Interdisciplinarios de América Latina y El Caribe, 16(1): 147-164. In http://www.nevusp.org/downloads/ down083.pdf. Accessed November 27, 2014.

Secretaria de Políticas para Mulheres - SPM (2006). Norma Técnica de Uniformização. Centros de Referência de Atendimento à Mulher em Situação de Violência. Brasilia: SPM - Presidência da República.

Soares, B.M. (1999). Mulheres invisíveis: violência conjugal e as novas políticas de segurança. Rio de Janeiro: Civilização Brasileira.

Soares, B.M. (2009). Violência entre parceiros íntimos e criminalização da vida privada: onde nos leva esse caminho? In Gênero, violência e direitos na sociedade brasileira. A.F. Moraes y B. Sorj, Orgs. Rio de Janeiro, 7Letras.

Sousa Santos, B. (1987). Notas sobre a história jurídico-social de Pasárgada. En O Direito Achado na Rua. J.G. Sousa Júnior, Ed. Brasília: Editora UnB.

Souza e Silva, J.; Barbosa, J.L.; Biteti, M.O. and Fernandes, F.L. (2009). O que é favela, afinal? Rio de Janeiro: Observatório de Favelas do Rio de Janerio. In http://observatoriodefavelas.org.br/wp-content/uploads/2013/09/o-que-é-favela-afinal.pdf. Accessed April 5, 2013.

Teixeira, P.A.S. and Pinto, A.S. (2014). Dossiê Mulher 2014. Rio de Janeiro: Riosegurança/ Instituto de Segurança Pública.

Teles, M.A.A. and Melo, M. (2003). O que é violência contra a mulher. São Paulo: Brasiliense. Valladares, L. (2005) A invenção da favela. Do mito de origem a favela.com. Rio de Janeiro: Ed. FGV.

Valladares, L. (2007). Os dez mandamentos da observação participante. Revista brasileira de ciências sociais, 22(63): 153-155. In http://www.scielo.br/pdf/rbcsoc/v22n63/ a12v2263.pdf. Accessed August 14, 2013.

Varella, D.; Bertazzo, I. and Berenstein Jacques, P. (2002). Maré, vida na favela. Rio de Janeiro: Casa da Palavra.

Wacquant, L. (2006). Os condenados da cidade: estudos sobre a marginalidade avançada. Rio de Janeiro: Revan, FASE.

Waiselfisz, J.J. (2015) Mapa da Violência 2015. Homicídio de Mulheres no Brasil. Brasilia: FLACSO Brasil. In http://www.mapadaviolencia.org.br/mapa2015_mulheres.php.

Weller, W. (2009). Tradições hermenêuticas e interacionistas na pesquisa qualitativa: a análise de narrativas segundo Fritz Schütze. En ANAIS da $32^{a}$ Reunião Anual da ANPED, 
Caxambu. In http://www.anped.org.br/reunioes/32ra/arquivos/trabalhos/gt14-5656--int. pdf. Accessed May 21, 2013.

Wetherell, M. and Potter, J. (1996). El análisis del discurso y la identificación de los repertorios interpretativos. En Psicologías, discursos y poder. A. Gordo y J. Linaza, Eds. Madrid: Visor. In http://gemma.atipic.net/pdf/326AD10405E.pdf. Accessed August 16, 2012.

Zurita Márquez, E. (2012). Rotas están las cuerdas. Violencia de género: una investigación antropológico-social. I Premio Fundación Alfonso Perales de Ensayo. Sevilla: Aconcagua Libros. 